\title{
Adverse Event Occurred with Overdose
}

National Cancer Institute

\section{Source}

National Cancer Institute. Adverse Event Occurred with Overdose. NCI Thesaurus. Code C83214.

An indication or description that an adverse event occurred with an overdose. 